\title{
Intersections
}

Canadian Journal of Music

Revue canadienne de musique

\section{John Beckwith and Robin Elliott, eds. Mapping Canada's Music: Selected Writings of Helmut Kallmann. Waterloo: Wilfrid Laurier University Press, 2013. 281 pp. ISBN 978-1-55458-891-6}

\section{Gordon E. Smith}

Volume 34, numéro 1-2, 2014

URI : https://id.erudit.org/iderudit/1030882ar

DOI : https://doi.org/10.7202/1030882ar

Aller au sommaire du numéro

Éditeur(s)

Canadian University Music Society / Société de musique des universités canadiennes

ISSN

1911-0146 (imprimé)

1918-512X (numérique)

Découvrir la revue

Citer ce compte rendu

Smith, G. E. (2014). Compte rendu de [John Beckwith and Robin Elliott, eds. Mapping Canada's Music: Selected Writings of Helmut Kallmann. Waterloo: Wilfrid Laurier University Press, 2013. 281 pp. ISBN 978-1-55458-891-6].

Intersections, 34(1-2), 216-221. https://doi.org/10.7202/1030882ar

Copyright @ Canadian University Music Society / Société de musique des universités canadiennes, 2015
Sntersections

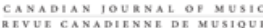

Ce document est protégé par la loi sur le droit d'auteur. L'utilisation des services d'Érudit (y compris la reproduction) est assujettie à sa politique d'utilisation que vous pouvez consulter en ligne.

https://apropos.erudit.org/fr/usagers/politique-dutilisation/ 
(Everist 2012, 17) 1 -are two factors that together make up the cultural history surrounding the life and works of a given composer. Schroeder's contribution therefore not only seeks to "make Mozart relevant to us in the twenty-first century" but also casts the net much wider in the writing of composer histories.

\section{WORK Cited}

Everist, Mark. 2012. Mozart's Ghosts: Haunting the Halls of Musical Culture. New York: Oxford University Press.

Roseen GiLes

John Beckwith and Robin Elliott, eds. Mapping Canada's Music: Selected Writings of Helmut Kallmann. Waterloo: Wilfrid Laurier University Press, 2013. 281 pp. ISBN 978-1-55458-891-6.

Helmut Kallmann is a pivotal figure in Canadian music studies and his passing in 2012 marked the end of an era that, in essential respects, he defined through more than a half-century of research on musical activities in Canadian music history. Mapping Canada's Music: Selected Writings of Helmut Kallmann ${ }^{2}$ is a collection of seventeen writings by Kallmann, a dozen of which have been previously published, and five presented in this volume for the first time. Among these are texts by Kallmann on historiographic perspectives related to Canadian music, including accounts of seminal publications such as Kallmann's $A$ History of Music in Canada 1534-1914 and the Encyclopedia of Music in Canada, and discussions of his work with institutions that contributed toward the rise of Canadian musical studies in the twentieth century, such as the Canadian League of Composers and the music division of the National Library of Canada. In addition, there are autobiographical writings by Kallmann that give the reader insight into the life story that shaped Kallmann's outlook and motivations. It is fitting that the editors of this volume are John Beckwith and Robin Elliott, ${ }^{3}$ both eminent scholars of Canadian music in the tradition of Kallmann. In the opening of the book's preface, Beckwith and Elliott explain that they first had the idea to recognize Kallmann's work in Canadian music by

1 Everist's study is a fresh look at Mozart reception and is also a nuanced study of the persistent and occasionally overlooked influence that Mozart has had on contemporary culture. Interestingly, Everist distinguishes two factors that make up Mozart's underlying societal significance: firstly reception, which is found chiefly in the scholarly realm, and secondly, renown, "a loose term, related to reputation, significance, and a host of other concepts that attribute value to cultural artifacts and their producers" (17), which resonates particularly with non-specialist readers of music literature.

2 The choice of the "map" metaphor for the book's title is an apt one. Readers will learn in various places through these writings of Kallmann's lifelong love of maps, reflected in telling ways in his approach to research and the representation of historical paradigms in Canadian music history in his publications.

3 John Beckwith was the inaugural Jean A. Chalmers Chair of Canadian Music and director of the Institute for Canadian Music at the Faculty of Music, University of Toronto, from 1984 until his retirement in 1990, and Robin Elliott is the current Jean A. Chalmers Chair and director of the ICM, a position he has held since 2003 . 
assembling a collection of his writings in 2011, and that, following Kallmann's death in 2012, "the book assumed the added significance of serving as a memorial to his life and work."

Mapping Canadian Music opens with two texts by the book's editors. The first of these, "Helmut Kallmann: A Brief Biography," begins with Kallmann's graduation in the first class of the Bachelor of Music school music program at the University of Toronto in 1949, and refers to Kallmann's comment under his graduation photo regarding his activities and future plans: "Music reviewer for The Varsity and Be Useful" (1). This reference provides telling insight into Kallmann's modesty, but also his strong work ethic. In addition to this snapshot of Kallmann's studies at the University of Toronto, the chapter contains biographical information about Kallmann, born in 1922 in Berlin into a Jewish family with leftist leanings, and which, during the 1930s, lost standing and subsequently suffered under Nazi persecution. Kallmann was fortunate to have been chosen to be part of the Kindertransport, a refugee program in London established to take young members of Jewish families to safety in England. This led to Kallmann's arrival in Canada via England in July 1940 as an internee, where he spent nearly three years in a series of internment camps in Quebec and New Brunswick, before he was released and allowed to move to Toronto in 1943. Early on, Kallmann was assisted in Toronto by his fellow internee, John Newmark, and Arnold Walter, took piano lessons with Naomi Adaskin and Greta Kraus, as well as finding employment at Coles bookstore. In this biographical account are a chronological survey of Kallmann's activities in Canada, including his appointments at the CBC Toronto music library in 1950 and the newly established music division of the National Library in 1970, and a discussion of his work in seminal institutional contexts, such as the Canadian League of Composers, the Canadian Music Library Association, Ten Centuries Concerts, and the Canadian Musical Heritage Society. Taken together, this work led to Kallmann's rise to national and international prominence as the expert on Canadian music history.

This is followed by "Helmut Kallmann and Canadian Music" in which the editors review the growth of research and writings since the mid-twentieth century. At the core of this growth was Kallmann's own research, his publications, and his influence on others. Beckwith and Elliott draw attention to themes in Kallmann's work that were formative in his views on historiography. Notable among these was the fact Kallmann was an immigrant to Canada, thereby bringing "an outsider's curiosity and perspective ... He [Kallmann] was part of a wave of mid-century émigré musicians who collectively exerted an enormous impact on the country's musical life" (17). As such, Kallmann played a role in the emergence of a modernist, cosmopolitan outlook beginning in the 1940s, gradually replacing the conservative, colonial tradition in music-making and music scholarship that had pervaded up until that time. Additionally, Kallmann's research was informed by his experience as an archivist and music librarian, and by "a passionate attachment to music as sound" (18) borne out by the fact he was a keen amateur pianist all of his life. Kallmann spent his career largely outside of academia, working for two of Canada's 
leading national cultural institutions, the $\mathrm{CBC}$ and the National Library of Canada. Significantly, the editors signal the influence of E. H. Carr's What Is History? on Kallmann's approach to historical representation. This influence includes viewing history as a chronological paradigm and studying generations and periods as a continuum.

These two introductory texts are greatly enhanced by Kallmann's own words in what follows in the rest of the book. For example, the opening reference to Kallmann's graduation from the University of Toronto is expanded upon in the heretofore unpublished 1949 text "Studying Music at a Canadian University 1946-1949 " (chapter 1), in which Kallmann reflects on his expectations as a student, the curriculum, the faculty, and his fellow students. The editors' choice to open these "selected writings" with this account creates an interesting parallel between the beginning of Kallmann's career as a music scholar and the beginning of formalized music study at the University of Toronto, a significant connection when one considers the later, and current, importance of $U$ of T's music program, nationally and internationally; this includes Canadian music studies, which both the editors have played key roles in developing.

"Canadian Music as a Field of Research" (chapter 2) is Kallmann's earliest published article on Canadian music (1950) and may be read as an entry point into Kallmann's later work. Of note here is the already present depth of historical perspective that guided his research. In Kallmann's words, "Musical life in Canada is richer and older than is generally assumed. Too often people write and speak as though music had not existed in Canada thirty or forty years ago ... A knowledge of our musical past would put the present into a clearer perspective and enable us to look into the future more assuredly" (36). Other critical frameworks for Canadian music identified by Kallmann include the importance of geography, migration patterns, and perhaps above all the need to consider how music informs the fabric of people's social and cultural lives. In chapter 3, "The New Grove's: Disappointment to Canada," Kallmann's meticulous scholarly approach to representing Canadian music sources accurately is seen in his response detailing corrections in the Canadian coverage to Eric Blom, editor of the fifth edition of The New Grove (1954).

The 1996 article, "Taking Stock of Canada's Composers from the 1920 s to the Catalogue of Canadian Composers (1952)" (chapter 13) was originally presented as a paper at a conference at the University of Victoria in 1988 celebrating the life and work of composer Murray Adaskin and his wife, the singer Frances James, and can be read as an important retrospective by Kallmann on his first assignment in musical lexicography when he was working for the $\mathrm{CBC}$ in the 1950s. The thoroughness in this work led to later assessments of the coverage of Canadian music in national and international publications (key examples are Beckwith 1969 and 1988) and became a model for such groundbreaking projects as the Encyclopedia of Music in Canada. Indeed, the EMC was a pivotal project in Kallmann's career and one in which his skill as "a born encyclopedist" (103), and his scholarly leadership, and capacity to inspire and work with others served in vital ways to see this enormous project through not one, but two, bilingual editions. Kallmann's story of the EMC is in chapter 10, "The 
Making of a One-Country Music Encyclopedia: An Essay after an Encyclopedia," a reprint of the 1994 article on the EMC Kallmann wrote for Fontis Artis Musicae.

Chapter 5, "Joseph Quesnel's Colas et Colinette," and chapter 7, "James Paton Clarke: Canada's First Mus. Bac.," can be regarded in parallel, as they are case studies mirroring the dual French (Quesnel) and English (Clarke) musical traditions in Canada. Indeed, Kallmann's work in the Archives du Séminaire in Quebec City, begun in the early 1950s, was pivotal in his discovery of the rich traditions of music-making in French Canada from the seventeenth to twentieth century. The Quesnel chapter is the program note for the 1963 Ten Centuries concert of Godfrey Ridout's reconstruction of Colas et Colinette, composed by Quesnel in the late eighteenth century and first performed in Montreal in 1790. Kallmann's research on this piece, "the first known performance of a Canadian opera" (53) as he called it, as well as on Quesnel's life and work, demonstrates his broad musicological reach, including consideration of historical, social, and cultural contextual frameworks, as well as informed discussion of the music. Kallmann's article on James Paton Clarke (1808-77), "the Scottish-born Canadian musical pioneer" (65; editors' words), published in The Canada Music Book / Les Cahiers canadiens de musique in 1970, provides a snapshot of nineteenth-century musical life in Toronto through the lens of this church musician and composer. Together these two texts provide a framework for the French-English dualism paradigm in much of Kallmann's work and, more generally, research in Canadian music through the second half of the twentieth century.

Kallmann's research approaches are also detailed in the introduction to his History of Music in Canada 1545-1914 (chapter 4). Influential Kallmann ideas are found in this text, including what Beverley Diamond has described as "two pervasive metaphors" $(1994,142)$ : "To appreciate the fascination of the subject [Music in Canada], one has to define musical history in Canada in different terms: such a history must deal with the planting of seeds rather than the harvesting of fruits" (44); and Kallmann's three-part critical framework: "Unity in Canada's musical history ... is found less in chronology, locale and musical repertoire than in the ever present themes of transplantation, assimilation, and the search for identity" (46). With respect to further critical thinking in Kallmann's work, readers may also wish to consider his contention that "most of the work done by musical researchers-call them musicologists, historians, music scholars, or whatever you wish - has or should have three dimensions ... 1) to clean up ... assemble and verify the facts ...;2) search for gold ... to judge the value of music ...; and 3) to observe connections ... to investigate the effect of one event or current person upon another-in short, the dynamics of musical history" (chapter 13, 168).

"Mapping Canada’s Music: A Life's Task" (chapter 15), one of the final texts Kallmann wrote on Canadian music, was solicited by a German music scholar, Graf Guido von Bimberg, for a collection of essays on Canadian music for the University of Augsberg's Institute for Canadian Studies series. Published in 1997, "Mapping Canada's Music: A Life's Task" is an excellent reflection by 
Kallmann on his career in Canadian music. Many of the themes and much of the information found in the early historical writings in Mapping Music: Selected Writings by Helmut Kallmann are synthesized by Kallmann here and are "mapped" onto a thorough sequential rendering of his career directions, research and publications, and related professional activities. Using telling subtitles such as "The Search," "First Applications," "Lacuna after Lacuna," "Collecting Canadiana," "A Lonely Task No Longer," and "In Retrospect, What Have I Learned?" Kallmann takes the reader on a guided tour of his groundbreaking, rich, and rewarding career.

The longest chapter is the final one, "At Home with the Kallmanns: A Schöneberg Family in the 1930s" (chapter 17). Previously an unpublished text that Kallmann wrote in German in the early 199os and translated with the assistance of his partner, Traute Weinberg, this is a fascinating account in which Kallmann guides us through his own life story, including his childhood and family life in Berlin, his departure in 1940 and arrival and new life in Canada (i.e., acquaintances, marriage to Ruth Singer), as well as the loss of his parents and sister, among many others who were part of his early life in Germany. Kallmann's voice in this powerful story maintains the same dispassionate tone found throughout his scholarly writings, but the deeply human level of this narrative builds through this text in ways that are truly moving. In a similar vein, in "Music in the Internment Camps and after World War II: John Newmark's Start on a Brilliant Canadian Career" (chapter 11), Kallmann provides an engaging account of his first years in Canada. Written as an article for the German-Canadian Yearbook and published in 1995, this story is on life in the camps through the lens of Kallmann's fellow internee, the Canadian pianist John Newmark, who went on to have a distinguished career in Canada as the accompanist of contralto Maureen Forrester. ${ }^{4}$

Mapping Canada's Music: Selected Writings of Helmut Kallmann is a valuable addition to the literature on Canadian music history. Themes that stand out include Kallmann's fascination for discovering the musical history of his adopted country, his dedication to forge directions and partnerships through his career, as well as to follow through with pivotal projects and publications that have been truly formative influences. Through the autobiographical writings in this collection we also learn of Kallmann's deeply human spirit, which undoubtedly gave him strength throughout his long life.

\section{Works Cited}

Beckwith, John. 1969. "About Canadian Music: The PR Failure." Musicanada 21 (July-August).

Beckwith, John. 1988. "A Failure Re-Visited: New Canadian Music in Recent Studies and Reference Works." In Hello Out There! ed. John Beckwith and

4 Kallmann and John Newmark were part of a significant group of Jewish immigrant to Canada in this period who went on to distinguished careers in music. Among others, these included Istvan Anhalt, Boris Berlin, Walter Homburger, Otto and Walter Joachim, Oskar Morawetz, Charles Reiner, and Heinz Unger. 
Dorith Cooper, 114-23, CanMus Documents 2, Institute for Canadian Music, University of Toronto.

Diamond, Beverley. 1994. "Narratives of Canadian Music History." In Canadian Music: Issues of Hegemony and Identity, ed. Beverley Diamond and Robert Witmer, 139-71. Toronto: Canadian Scholars' Press.

Gordon E. SMITH

William Todd Schultz. 2013. Torment Saint: The Life of Elliott Smith. New York: Bloomsbury. 368 pp. ISBN 978-1-60819-973-0.

Elliott Smith entered mainstream consciousness during a surrealistic performance at the 1998 Academy Awards ceremony. Unintentionally evoking the absurdist strategies of early Dadaists such as Hugo Ball, the greasy-haired Smith took the stage in a white Prada suit opposite Jack Nicolson; in other words, a sore thumb amidst rows of Hollywood elite. His song "Miss Misery," which appeared in Gus Van Sant's 1997 film Good Will Hunting, had been nominated in the Best Original Song category. Although he eventually lost to Celine Dion's "My Heart Will Go On," Smith was hardly disappointed. Here was a master craftsman of lyricism and melody, arguably one of the greatest of the 1990s, moving towards wider audience and industry recognition.

William Todd Schultz's Torment Saint: The Life of Elliott Smith attempts to separate what he calls "The Smith Myth" from reality by approaching the musician's life through rigorous biographical study. Schultz is one of the foremost thinkers in "psychobiography" - a developing field of research that integrates biographical scholarship with psychological theory-having published the Handbook of Psychobiography (Oxford) in 2005. That being said, although this book does not explicitly apply psycho-biographical theory to Smith's life and music, it is written and reads as biography.

The introductory chapter and much of chapter 1 reconcile the lure of conflating Smith with the "tragic hero" archetype that he and many of his contemporaries such as Kurt Cobain and Daniel Johnston fall into. The latter is regarded as an "outsider" singer, songwriter, and visual artist, who was memorialized in the 2005 documentary The Devil and Daniel Johnston. According to Schultz, the hero is more or less "a blameless victim of wrongdoing. The hero stays pure. The hero is martyred" (8). Recognizing that romanticization shuts down meaning and the dynamic complexity of the musician's personal history, Schultz, much to his credit, inevitably finds Smith's music as a fundamental producer of meaning, rather than fleshing out meaning from biographical details alone.

A central problem that Schultz encounters with Smith is his plurality; for Schultz, "There are too many Elliott Smiths to count" (1). An avid reader of Kafka, Stendhal, and Freud, Smith wrote his undergraduate thesis at Hampshire College on post-structural feminist theory in law proceedings, citing Derridean "misreadings" and fluidity of interpretation (103). Applying such critical theory might have allowed Schultz to speculate on the sources of 